\title{
PERAN KOMUNIKASI DIREKTORAT SAMAPTA BHAYANGKARA KEPOLISIAN DAERAH KALIMANTAN TENGAH (DITSABHARA POLDA KALTENG) DALAM PENINGKATAN PATROLI DIALOGIS DI KOTA PALANGKA RAYA
}

\author{
Communication Role Of Directorate Samapta Bhayangkara Police Of Central \\ Kalimantan Region (Ditsabhara Polda Kalteng) In The Improvement Of Dialogis Patrol \\ In The City Palangka Raya
}

Junaidi*

Dwi Priya Utama

Universitas Muhammadiyah Palangkaraya, Palangka Raya, Central Kalimantan, Indonesia

email:

junaidi@umpalangkaraya.ac.id

Kata Kunci:
Peran
Komunikasi
Dialogis

Keywords:
Role
Communication
Dialogical

Accepted

January 2019

Published

April 2019

\begin{abstract}
Abstrak
Penelitian ini bertujuan untuk menjelaskan dan mendeskripsikan Peran Komunikasi Direktorat Samapta Bhayangkara Kepolisian Daerah Kalimantan Tengah (Ditsabhara Polda Kalteng) Dalam Peningkatan Patroli Dialogis Di Kota Palangka Raya. Metode penelitian yang digunakan adalah metode penelitian kualitatif, dengan menggunakan teknik pengumpulan data melalui observasi, wawancara dan dokumentasi. Sumber data dalam penelitian ini yaitu anggota subditgasum Ditsabhara Polda Kalteng dan beberapa masyarakat yang ada di Kota Palangka Raya.

Berdasarkan hasil penelitian Peran Komunikasi Direktorat Samapta Bhayangkara Kepolisian Daerah Kalimantan Tengah (Ditsabhara Polda Kalteng) Dalam Peningkatan Patroli Dialogis Di Kota Palangka Raya sudah cukup baik, akan tetapi respon dari masyarakat dalam memberikan informasi masih belum baik. Peneliti menunjukan bahwa pihak Direktorat Samapta Bhayangkara Polda Kalteng dalam hal ini melalui Subdit Gasum sebagai pelaksana patroli telah melakukan perannya dalam berpatroli sebagai upaya pencegahan dan meminimalisir gangguan kamtibmas dengan baik. Akan tetapi pada pelaksanaan tugas patroli anggota kepolisian mendapat hambatan dari masyarakat berupa minimnya tanggapan maupun informasi yang diberikan oleh masyarakat itu sendiri dalam upaya mendukung terwujudnya situasi kamtibmas yang tetap kondusif.
\end{abstract}

\begin{abstract}
This research aims to explain and describe the communication role of the Directorate of Samapta Bhayangkara Police of Central Kalimantan region (Ditsabhara Polda Kalteng) in the improvement of Dialogical patrol in the city Palangka Raya. The research methods used are qualitative, using data collection techniques through observation, interviews, and documentation. The data sources in this research are members of Subditgasum Ditsabhara Polda Kalteng and some of the communities in the city of Palangka Raya.

Based on the research of Communication role of Directorate Samapta Bhayangkara Police of Central Kalimantan region (Ditsabhara Polda Kalteng) in the improvement of Dialogical patrol in the city Palangka Raya is good enough, but the response from the community in Provide information still not good. Researchers have indicated that the Directorate of Samapta Bhayangkara Polda Kalteng in this matter through Subdit Gasum as a patrol officer has been doing its role in patrolling as a preventive effort and minimize the disturbance of the Kamtibmas well. However, in the implementation of police patrol tasks get barriers from the community in the form of lack of responses and information provided by the community itself to support the situation of the environment that remains conducive.
\end{abstract}

\section{PENDAHULUAN}

Tugas kepolisian yang dinilai paling efektif untuk menanggulangi terjadinya kejahatan dalam penanggulangan dan pengungkapan suatu tindak pidana adalah tugas preventif (pencegahan). Preventif dilakukan dengan 4 kegiatan pokok yaitu mengatur, menjaga, mengawal dan patroli.

Patroli merupakan kegiatan yang dominan dilakukan, karena berfungsi untuk mencegah bertemunya faktor niat dan kesempatan agar tidak terjadi gangguan 
keamanan dan ketertiban masyarakat atau pelanggaran hukum dalam rangka upaya memelihara atau meningkatkan tertib hukum dan upaya membina ketentraman masyarakat untuk mewujudkan atau menjamin keamanan dan ketertiban masyarakat. Dalam menjalankan tugasnya, Ditsabhara Polda Kalteng saat ini mengedepankan pendekatan kepada masyarakat dengan cara melakukan patroli dialogis.

Tujuan lain dari pelaksanaan patroli dialogis ini adalah untuk mencegah terjadinya kejahatan sekaligus meningkatkan kedekatan polisi dengan masyarakat. Akan tetapi pada kenyataan di lapangan menggambarkan bahwa sebagian masyarakat bersikap acuh ketika anggota patroli dialogis Ditsabhara Polda Kalteng mendatangi dan mengajak berinteraksi dengan mereka. Hal tersebut dapat dilihat ketika adanya sekelompok masyarakat berjumlah sepuluh orang yang sedang berkumpul di kawasan terminal lalu yang menyambut baik dan berinteraksi dengan anggota patroli hanyalah satu atau dua orang saja, sedangkan yang lainnya terlihat sibuk dengan main kartu dan juga handphone. Selain itu masyarakat juga kurang aktif dalam menyampaikan informasi maupun melaporkan tentang situasi kamtibmas yang ada dilingkungan sekitarnya. Masyarakat cenderung melaporkan ke pihak berwajib dalam hal ini kepolisian apabila sudah terjadi kasus kriminal maupun tindakan-tindakan serupa yang berkaitan dengan masalah gangguan kamtibmas lainya.

Dari beberapa kejadian gangguan kamtibmas yang terjadi di wilayah kota Palangka Raya seharusnya bisa diminimalisir atau ditangani dengan cepat apabila masyarakat berani melaporkan atau memberikan informasi secepat mungkin ke kepolisian. Tetapi masyarakat banyak yang tidak berani untuk melaporkan adanya kegiatan - kegiatan yang memicu gangguan situasi kamtibmas dengan berbagai alasan. Sebagian masyarakat merasa takut apabila adanya perbuatan balas dendam dari orang yang dilaporkan. Selain itu masyarakat tidak mau dijadikan saksi oleh kepolisian apabila melapor dengan alasan waktu yang akan mengganggu aktifitasnya.

Patroli dialogis merupakan salah satu bentuk program reaksi cepat kepolisian yang seharusnya dapat dimanfaatkan oleh masyarakat sehingga dengan informasi cepat yang didapat dari masyarakat maka setidaknya kepolisian akan lebih cepat juga dalam meminimalisir gangguan kamtibmas. Kurang aktifnya masyarakat dalam menanggapi dan memberikan informasi situasi kamtibmas terhadap kepolisian menggambarkan bahwa tidak ada kedekatan yang baik antara masyarakat dan kepolisian. Hal ini menjadi tantangan bagi kepolisian dalam meningkatkan komunikasi dengan masyarakat sebagai bentuk dari kegiatan patroli dialogis.

Persoalan komunikasi yang paling menjadi perhatian adalah bagaimana komunikasi yang kita lakukan bisa efektif terhadap orang lain. Itu bisa berarti mencari dukungan, membina hubungan, mempengaruhi orang lain agar mau melakukan apa yang kita inginkan, menetapkan keputusan, meminta anggota masyarakat untuk melakukan program pemerintah, dan berbagai hubungan profesional lainnya (Depdagri-LAN dalam Hardiyansyah, 2015:14).

Pelaksanaan patroli dialogis ini tentunya membutuhkan persyaratan kemampuan antara lain kemampuan komunikasi yang baik serta pengetahuan tentang karakteristik kerawanan wilayah penugasan oleh para personel/petugas pelaksana patroli. $\mathrm{Hal}$ ini dimaksudkan agar personel patroli mampu berinteraksi dengan baik kepada masyarakat sehingga target untuk mencegah atau mengantisipasi tindak kejahatan jalanan maupun kejahatan di lingkungan dapat tercapai dengan baik. Selain itu yang tidak kalah pentingnya untuk menjaga situasi kamtibmas tetap kondusif adalah peran aktif dari seluruh masyarakat itu sendiri. 


\section{METODOLOGI}

Dalam penelitian ini menggunakan pendekatan kualitatif sebagai prosedur penelitian yang digunakan untuk meneliti pada kondisi objek yang alamiah di mana peneliti adalah sebagai instrumen kunci, pengambilan sampel sumber data dilakukan secara purposive, teknik pengumpulan dengan triangulasi, analisis data bersifat induktif/kualitatif, dan hasil penelitian kualitatif lebih menekankan makna daripada generalisasi.

Penelitian ini dilakukan pada Kantor Direktorat Samapta Bhayangkara Kepolisian Daerah Kalimantan Tengah (Ditsabhara Polda Kalteng) serta beberapa lokasi lingkungan tempat tinggal masyarakat yang berada diwilayah Kota Palangka Raya dengan alasan karena memiliki potensi tingkat kerawanan gangguan kamtibmas. Kemudian, Sumber data primer diperoleh melalui wawancara langsung dengan narasumber yang dapat menjawab permasalahan yang ada yaitu Kasubdit Gassum Ditsabhara Polda Kalteng dan unsur masyarakat pada beberapa lokasi tertentu. Sedangkan sumber data sekunder berdasarkan dokumen, artikel dan bahan bacaan lain untuk mendukung penelitian ini.

\section{HASIL DAN PEMBAHASAN}

Ditsabhara Polda Kalteng memiliki peran yang sangat penting dalam melaksanakan tugas-tugas kepolisian, diantaranya adalah kegitan patroli dialogis yang diharapkan setidaknya mampu menimalisir terjadinya tindak kejahatan maupun gangguan kamtibmas lainya. Selain itu patroli dialogis ini juga lebih menekankan komunikasi yang baik antara kepolisian dengan masyarakat agar terjalin kedekatan serta hubungan yang baik diantara keduanya. Untuk itu komunikasi yang baik diantara keduanya sangat diperlukan. Dengan tidak adanya komunikasi yang baik antara polisi dan masyarakat akhirnya timbul sikap masyarakat yang menghindarkan diri untuk berurusan dengan polisi. Sehingga apabila menjadi korban tindak kejahatan dan hanya mengalami sedikit kerugian maka masyarakat cenderung mengurungkan niatnya untuk melaporkan ke polisi. Sebagai unit yang sering bersinggungan langsung dengan masyarakat, patroli polisi harus bisa menempatkan diri sebagai sosok yang dekat dengan masyarakat namun juga harus tegas serta berwibawa.

Dalam melakukan penelitiaan ini peneliti mengacu pada Teori Tubbs dan Moss (2008:23-28) dengan berdasarkan lima indikator Komunikasi yaitu pemahaman, kesenangan, mempengaruhi sikap, memperbaiki hubungan, dan tindakan. Berdasarkan analisis terhadap data yang diperoleh, maka hasil penelitian yang peneliti peroleh adalah sebagai berikut:

I. Pemahaman

Pada indikator pemahaman ini terdapat banyak kesamaan pemahaman antara anggota patroli dengan masyarakat baik dari segi pengetahuan peta wilayah maupun prosedur pelaporan. Akan tetapi masih ada sebagian masyarakat yang kurang memahami cara berkomunikasi yang baik saat berinteraksi maupun berdialog.

2. Kesenangan

Pada indikator kesenangan peneliti menemukan adanya kesamaan perasaan suka berinteraksi secara umum antara anggota patroli dan masyarakat, meskipun masih ada sebagian masyarakat yang memilih-milih interaksinya berdasarkan kepentingan mereka sendiri.

3. Mempengaruhi Sikap

Pada indikator pengaruh pada sikap ini peneliti menemukan adanya perilaku sebagian masyarakat yang masih kurang aktif dengan pesan atau makna yang diterima saat berdialog, dengan masih mengedepankan kepentingan sendiri dengan hanya melakukan seperlunya.

4. Memperbaiki Hubungan

Pada indikator ini, peneliti menemukan adanya hubungan yang makin baik antara polisi dengan masyarakat, meskipun masih terdapat beberapa masyarakat yang menginginkan kedekatan yang 
lebih baik dengan memanfatkan kemajuan teknologi.

5. Tindakan

Pada indikator tindakan, peneliti menemukan adanya sebagian besar masyarakat yang tidak berani mengambil tindakan dengan melaporkan ke anggota patroli maupun kepolisian saat melihat terjadinya gangguan kamtibmas dilingkungan masyarakat. Hal tersebut dikarenakan ketidakmauan mereka menjadi saksi dan takut apabila ada unsur balas dendam dari yang dilaporkan. Selain itu sebagian masyarakat lebih mengutamakan melapor ke petugas jaga keamanan lingkungan setempat.

Dalam menjalankan tugas patroli dialogis sebagai langkah pencegahan dan penanggulangan kejahatan pihak anggta patroli Ditsabhara Polda Kalteng mendapat beberapa hambatan, adapun beberapa hambatan tersebut sebagai berikut :

\section{Masyarakat Kurang Berpartisipasi}

Kurangnya pengetahuan masyarakat tentang pentingnya suatu keamanan. Seharusnya masyarakat jangan hanya menyerahkan tugas kamtibmas kepada kepolisian, tetapi masyarakat juga harus berperan dalam menjaga keamanan. Masyarakat memiliki peran yang sangat besar dalam upaya penanggulangan kejahatan dimana polisi sangat membutuhkan masuknya laporan dari masyarakat atas ada kegiatan atau orang mencurigakan yang akan menjurus atau melakukan tindak kejahatan. Banyak masyarakat yang enggan untuk melaporkan atau memberikan informasi tentang akan atau sedang atau setelah terjadinya suatu tindak pidana dan lebih menghindar untuk berurusan dengan polisi.

2. Sikap Masyarakat

Berdasarkan hasil yang diperoleh peneliti dilapangan menggambarkan bahwa sebagian masyarakat yang berada pada lokasi tertentu di
Kota Palangka Raya menggambarkan adanya sikap masyarakat yang kurang responsif kurang menyambut baik anggota patroli yang datang mendatangi mereka. Misalnya saja seperti yang terlihat di salah satu pusat perekonomian masyarakat di Kota Palangka Raya dimana dari sejumlah masyarakat yang berada dilokasi tersebut hanya satu atau dua orang saja yang mau menyambut dengan baik dan berinteraksi dengan anggota patroli.

3. Lingkungan Tempat Tinggal

Berdasarkan hasil penelitian yang diperoleh peneliti dilapangan menggambarkan bahwa sebagian masyarakat yang tinggal di rumah kontrakan maupun kos-kosan Kota Palangka Raya kurang aktif dalammelakukan proses komunikasi dengan anggota patroli. Saat berjalanya komunikasi, sebagian masyarakat tersebut cenderung menutup diri dengan tidak memberikan banyak informasi maupun respon yang baik. Hal tersebut dikarenakan mereka mengaku hanya sebagai penyewa tempat tinggal tersebut dan bukan asli masyarakat setempat sehingga jarang terjadi interaksi dengan masyarakat setempat.

4. Kondisi Geografis

Kondisi geografis Kota Palangka Raya yang tidak semuanya dapat ditempuh melalui jalur darat sehingga harus melalui jalur sungai seperti yang ada di Kelurahan Mangku Baru, Kecamatan Rakumpit Kota Palangka Raya sehingga sulit dijangkau oleh anggota patroli dialogis Ditsabhara Polda Kalteng yang menggunakan kendaraan dinas transportasi darat dalam kegiatan rutin pelaksanaan patroli.

5. Masyarakat Yang Majemuk

Masyarakat yang berada di Kota Palangka Raya memiliki aneka ragam perbedaan baik tingkat SDM maupun status sosial. $\mathrm{Hal}$ ini mengakibatkan sebagian masyarakat diantara mereka tidak saling mengenal dengan baik karena mereka memiliki 
kepentingan sendirisendiri. Hal ini tentunya menjadi salah satu hambatan dalam berinteraksi.

\section{KESIMPULAN}

Berdasarkan analisis dari hasil penelitian dilapangan tentang Peran Komunikasi Direktorat Samapta Bhayangkara Kepolisian Daerah Kalimantan Tengah (Ditsabhara Polda Kalteng) Dalam Peningkatan Patroli Dialogis Di Kota Palangka Raya maka dapat ditarik kesimpulan Bahwa prosedur pelaksanaan patroli dialogis Ditsabhara Polda Kalteng mengacu pada Perkap Baharkam Polri No.l Tahun 2017 tentang Patroli ini masih belum maksimal dengan kurangnnya pemahaman masyarakat untuk berinteraksi dan berdialog yang masih belum aktif. Hal ini dilihat dari interaksi dari sebagian masyarakat yang memilih-milih interaksinnya dalam arti masih mengedepankan kepentingan individu saja. Apalagi ketidakmauan masyarakat untuk mengambil tindakan dengan melaporkan ke anggota patroli, kasus ini terjadi dengan alasan masyrakat takut menjadi saksi apabila ada unsur balas dendam dari yang dilaporkan.

Dalam menjalankan tugas patroli dialogis, Distsabhara Polda Kalteng mendapat beberapa hambatan, antara lain:

I. Masyarakat Kurang Berpartisipasi

2. Sikap Masyarakat yang kurang Responsif dengan menyambut baik anggota patroli

3. Lingkungan Tempat tinggal yang membuat sebagian masyarakat menutup diri

4. Kondisi Geografis yang menjadi keterbatasan untuk menjangkau semua wilayah

5. Masyarakat yang majemuk yang menadi hambatan dalam berinteraksi.

\section{REFERENSI}

Agustino, Leo. 2017. Dasar - dasar Kebijakan Publik. Alfabeta. Bandung.

Aw, Suranto. 2010. Komunikasi Sosial Budaya. Graha Ilmu. Yogyakarta.

Aw, Suranto. 2011. Komunikasi Interpersonal. Graha Ilmu. Yogyakarta.

Hardiyansyah. 2015. Komunikasi Pelayanan Publik Konsep dan Aplikasi. Gava Media. Yogyakarta.

Moss, Sylvia dan Stewart L Tubbs. 2008. Human Communication. PT Remaja Rosdakarya. Bandung.

Mulyana, Deddy dan Rakhmat Jalaluddin. 1996. Komunikasi Antar Budaya Panduan Berkomunikaasi Dengaan Orang - Orang Berbeda Budaya. PT Remaja Rosdakarya. Bandung.

Mulyana, Deddy. 2007. Ilmu Komunikasi Suatu Pengantar. PT Remaja Rosdakarya. Bandung.

Robbins, P Stephen. 2003. Perilaku Organisasi. PT Indeks, Gramedia Grup. Jakarta.

Soekanto, Soerjono. 2018. Sosiologi Suatu Pengantar. PT Raja Grafindo Persada. Jakarta.

Sugiono. 2015. Metode Penelitian \& Pengembangan Research and Development. Alfabeta. Bandung. . 20II, Pedoman Pelaksanaan Pelayanan Publik Melalui Kegiatan Turjawali Sabhara. Markas Besar Kepolisian Negara Republik Indonesia.

-. 2011, Patroli. Markas Besar Kepolisian Negara Republik Indonesia.

2014, Modul Fungsi Teknis Sabhara. Markas Besar Kepolisian Negara Republik Indonesia. - 2017. Peraturan Kepala Badan Pemelihara Keamanan Kepolisian Negara Republik Indonesia (Perkap Baharkam Polri) Nomor I Tahun 200I 7. Markas Besar Kepolisian Negara Republik Indonesia. 